Article

\title{
Sustaining Regional Advantages in Manufacturing: Skill Accumulation of Rural-Urban Migrant Workers in the Coastal Area of China
}

\author{
Huasheng Zhu ${ }^{1, *}$, Junwei Feng ${ }^{1}$, Maojun Wang ${ }^{2}$ and Fan $\mathrm{Xu}{ }^{1,3}$ \\ 1 Faculty of Geographical Science, Beijing Normal University, Beijing 100875, China; \\ fjunw@mail.bnu.edu.cn (J.F.); rzjtghk@163.com (F.X.) \\ 2 College of Resources Environment and Tourism, Capital Normal University, Beijing 100048, China; \\ maojunw@yeah.net \\ 3 Rizhao Transportation Bureau of Shandong, Rizhao 276800, China \\ * Correspondence: zhuhs@bnu.edu.cn; Tel.: +86-10-5880-0193
}

Academic Editors: Hongbo Liu, Sizhong Sun and Iain Gordon

Received: 12 September 2016; Accepted: 3 January 2017; Published: 7 January 2017

\begin{abstract}
Extant research pays little attention to unorganized migrant workers' skill accumulation/upgrading from the perspective of the labor supply. This paper takes China as an example to explore the factors influencing the skill accumulation of rural-urban migrant workers (RUMWs), with the purpose of discovering how to sustain or reshape regional competitive advantages by improving RUMWs' skill accumulation. Structured questionnaire surveys were adopted for data collection in Suzhou City, Jiangsu Province and Taizhou City, Zhejiang Province located in the Yangtze River Delta in eastern China. In total, 700 questionnaires were issued and 491 effective questionnaires were recovered. It takes the perspective of individual laborers, with special regard to the effects of localization on the laborers' skill accumulation within the context of globalization. It adopts a broad viewpoint including intra-firm skill-biased strategy (as a response to intense competition), inter-firm relationships, and the accessibility of local non-firm organizations. The findings indicate that firms' skill preference, which impacts employees' skills and innovation ability and stimulates them to learn with initiative, have a significant influence on RUMWs' skill accumulation. In terms of collective efficiency based on the co-competitive relationship between local firms, the more intensive interactions are, the more opportunities RUMWs are afforded for skill accumulation. The accessibility of local institutions and favorable policies also benefit RUMWs' skill accumulation. In addition, the place itself, as a synthesized space of a firm's internal labor-management relations and inter-organizational relations, also exerts an influence on and causes regional differences in RUMWs' skill accumulation.
\end{abstract}

Keywords: skill accumulation; regional advantages; rural-urban migrant workers; industrial clusters

\section{Introduction}

Human capital growth or skill accumulation/upgrading of labor (for ordinary laborers, skills and competencies are crucial components of human capital, and they can generate productivity, and in turn drive economic growth [1]; therefore, in this paper, the authors regard workers' human capital as vocational skills) influences industrial transformation, upgrading, and reconstruction, and sustains the competitive advantage of less developed countries (LDCs), particularly in the era of globalization [2]. The extant literature on skill upgrading is mainly within the field of international economics, which is concerned with the relationship between trade and employment. Based on the view of comparative advantage, the Heckscher-Ohlin theorem and Stopler-Samuelson theorem (HOSS hereafter) predict that trade with or foreign direct investment (FDI) from developed countries would make developing countries specialize in labor-intensive activities and increase the demand for unskilled 
labor [3,4], meaning that LDCs benefit little for their skill upgrading from international trade. Contrary to this prediction, another line of literature on the interlinks among globalization (export, import, and FDI), technological transfer, innovation, employment, and skill upgrading, argues that trade and FDI encourage firms in LDCs to engage in product innovation and hire workers with higher levels of skills, which sustains competitive advantages and leads to skill upgrading [5-8]. Furthermore, it is considered that compared to accepting FDI, export trade cannot significantly promote skill upgrading for firms [9]. This in turn implies that different means of integration into the global economy may cause differences in workers' skill upgrading in different countries and regions. However, currently there is still insufficient discussion in this regard.

In addition, much of the relevant research focuses on the relationships between globalization and skill upgrading, but pays little attention to the national or local absorptive capacities, which are related to institutional setting, labor skills, technological capabilities, and competitiveness of domestic firms, and have effects on the skill upgrading of a specific country or place [3]. Actually, the experiences from some LDCs have indicated that integration into global production networks could not help them realize a shift from lower-value-added activities to higher-value-added activities (let alone workers' skill upgrading), and these countries turn to build up their national value chains [10]. Therefore, it needs to examine the national or local determinants influencing laborers' skill upgrading within the context of globalization, which is an important reason for the authors to carry out this research. From the perspective of labor demand instead of the supply side, the findings show that the proportion of workers with higher skills significantly increases with the opening up of a country; however, little evidence indicates whether this improvement is a consequence of individual workers' skill accumulation or that of the replacement of low-skill workers with high-skill workers. Furthermore, the process of globalization is believed to be beneficial to skillful workers as a whole, while having an opposing effect on unskilled workers [11]. Therefore, different groups of laborers deserve further investigation in terms of their skill accumulation. The discussion of unorganized labor, especially migrant workers outside the mainstream labor market, is also currently insufficient.

Skill accumulation/upgrading of rural-urban migrant workers (RUMWs, labor with a census register in a rural area which migrates to cities for employment) in China is a topic worthy of discussion. In coastal areas in particular, foreign trade and FDI have been developing rapidly, and the local industrialization process has been accelerating since China's reforms and opening up of the late 1970s. Consequently, abundant RUMWs have swarmed into such areas and become the main force of urban industries [12]. According to the national rural-urban migrant monitoring and investigation data of 2013, the number of RUMWs in secondary and tertiary industries already exceeded half the number of the total employed population [13]. Due to the restrictions of the urban-rural dual structure (due to the household registration system (HRS) in China, farmers do not have access to social welfare and full citizenship in cities, even if they have worked there for many years, whereby HRS actually segregates the rural and urban populations in geographical, social, economic, and political terms, and leads to two different social classes: the urban class, whose members work in the prioritized and protected industrial sector and who have access to social welfare and full citizenship, and the farmers, who are tied to the land in the agricultural sector and fend for themselves [14]), and to their low educational backgrounds and low labor skills, it is believed that most RUMWs have engaged in physical work with low technology and low wage levels for a long time, and therefore live in the bottom social level of cities [15]. With the transference of labor-intensive industries to other countries and economic transition from "Made in China" to "Create in China" in recent years, the coastal areas have begun to reconstruct their competitive advantage by relying more on high quality human capital than on the high quantities of labor. Compared with the increasing demand for high-level skilled workers, the competition for low-skill posts has intensified, and many RUMWs are facing an unemployment crisis. As a result, a structured labor shortage has emerged [16]. Under such circumstances, improving RUMWs' skills could not only sustain the industrial upgrading of developed regions but also help these workers adapt to the economic transformation and ensure the sustainability of their urban lives. The Chinese government has already realized the importance of improving the RUMWs' vocational skills, and has adopted successive policy initiatives such as the "Spring 
Breeze Action" and the "Sunshine Project" since 2004, especially putting this issue into the National New Urbanization Planning (2014-2020). Furthermore, the Rural-Urban Migrant Work Leading Group of the State Council has deployed the implementation of the "Rural-Urban Migrant Vocational Skill Improvement Plan" for the annual training of more than 20 million people nationwide since 2014 [17]. However, most of the current research focuses on the social integration of RUMWs into cities, but fails to discuss their skill upgrading or accumulation [15]. A small amount of research mainly focuses on the institutional restraints from a nationwide standpoint, such as the urban-rural dual barrier and the household registration system [14,18], but is lacking in a survey that considers both the factors concerning firms and regions and the wider context of globalization. Therefore, this paper integrates international economics literature with industrial clusters research (rather than focusing solely on the perspective of globalization as international economics literature does), selects the Chinese eastern coastal area, and discusses the main factors influencing RUMWs' skill accumulation from the perspective of individual laborers on three levels: intra-firm strategy as a response to intense competition, local inter-firm relations, and the accessibility of local non-firm institutions.

\section{Literature Review and Main Hypotheses}

\subsection{Labor, Migration, and Human Capital Growth/Skill Upgrading}

It is considered that human capital growth can be achieved through certain investments in medical treatment and health care, on-the-job training, regular education, and non-business adult education, and can obtain certain beneficial returns, such as an increase in personal income [19-21]. Laborers' individual attributes, including age, gender, educational background, work experience, career goals, etc., influence the intention and capability for personal investment in human capital, and as such further influence human capital growth [22-24]. Migration is also regarded to improve the human capital level by two promoting effects: forward stimulation before migration and the subsequent acquisition of relearning opportunities after migration [25]. With respect to the former effect, if opportunities for employment transfer to foreign countries increase, the workers in underdeveloped regions will be stimulated to take the initiative to improve their human capital to improve their possibility of employment transfer [26]. In terms of the latter effect, farmers who transfer from agriculture in rural areas to non-agricultural industry in cities can increase their human capital through "learning by doing", on-the-job training [27], and vocational skills training courses provided by local government or NGOs [28,29]. Additionally, the employment experience in cities forms a certain degree of integration with various kinds of capabilities and competencies, which also improves their human capital. As a result, the urban-rural labor flow is regarded as an important source of economic development for urban areas [30], and returning RUMWs can be considered as an engine driving the development of their hometowns through their accumulation of financial capital and human capital acquired during migration [31].

However, another line of literature in China argues that the flow of RUMWs into a city does little to help the floating population with skill accumulation. Discrimination against RUMWs based on wage, employment, and welfare exists in the urban labor market as a result of the urban-rural dual system (household registration system, education system, employment system, insurance system, labor system, etc. formed on the basis of urban-rural separation administration system). The marginalization of employment and living, and the frequent job-hopping bring a certain degree of decomposition to the RUMWs' human capital after migration to cities [18]. Meanwhile, the new-generation of RUMWs have more opportunities to choose jobs, they can better prepare vocational skills before migration, and thus they better adapt to city life compared with elder generations. However, due to frequent career choice and employment flow, it is not beneficial for them to make sustainable investment in human capital and accumulate vocational skills [32]. Furthermore, there is a dispute regarding the influence of immigration-targeted cities on RUMWs' human capital growth and skill accumulation. One line of literature believes that RUMWs in big cities have more opportunities for human capital growth and skill accumulation than those in small cities because of the favorable employment environments and better service facilities in big cities [33]. Another line of literature holds the view that it is difficult for RUMWs to enjoy such treatment and to promote skill accumulation in big cities due to the restrictions on their leisure time and financial capital, and to the low accessibility of urban public resources [34]. 


\subsection{Globalization, Innovation, and Skill Upgrading}

\subsubsection{Trade, FDI, and Skill Upgrading}

International economics discusses skill upgrading within the context of trade liberalization [35,36], openness [37], or globalization [4,38] in developing countries. According to the Heckscher-Ohlin model, both trade and FDI take advantage of the abundance of labor in developing countries and make these countries specialize in labor-intensive activities. As a result, their domestic employment increases. The Stolper-Samuelson theorem makes a further prediction that there would be an increasing demand for domestic unskilled labor compared to skilled labor in LDCs, and that the wage inequality between unskilled and skilled labor would decrease. From the perspective of the HOSS prediction, increasing trade lowers the demand for skilled labor in LDCs, implying that openness provides little benefit or even hinders skill upgrading in these countries.

However, the recent literature does not totally support the HOSS prediction. Export growth may raise employment, but imports may displace previously protected domestic industries and firms, thereby decreasing the demand for labor [3]. As Lall points out, the HOSS theorem is based on the endowments of two factors within perfect markets, but ignores imperfections which determine industrial efficiency and competitiveness, such as technological leads and lags, scale and agglomeration economies, product differentiation, and so forth [38]. Competitive capabilities vary from country to country in the developing world, and the impact of increasing trade on employment and wage equality between unskilled and skilled labor is complex but not necessarily positive $[3,35,38]$. For example, since the enactment of trade reform in Mexico, there has not been an increase in employment, but there has been a dramatic increase in the skilled-unskilled wage gap. This is mainly because it has a relative scarcity of un-skilled labor and an abundance of skilled labor compared with China and other countries [35]. In terms of skill upgrading, it has been proven that trade and technological change are complementary rather than alternative mechanisms [36]. International openness may increase the trade of capital goods, such as skill-intensive machinery embodying technological innovations, and facilitate technology diffusion from industrialized to LDCs. As Robbins' (1996) [39] skill-biased enhancing trade hypothesis argues, the imports of skill-biased machinery, which are probably outdated in developed countries but are relatively advanced compared to the existing machinery in LDCs, can increase the demand for skilled labor in LDCs. International activities are also considered to induce and foster skill-biased technological change [36]. Due to openness, domestic companies in LDCs have been exposed to increasingly serious competition, forcing them to adapt to modern skill-intensive technologies to sustain the competitiveness of their products [40]. Moreover, international activities concerning imports, exports, and FDI mean that cross-national relationships are established with foreign suppliers, customers with high-level tastes, and multinational companies. These relationships facilitate domestic firms with gaining access to tacit knowledge, especially that knowledge which is not easily transferred via market transactions. The interplay between trade openness and technology adoption plays a critical role in shifting the labor demand towards more skilled workers, pushing forward skill upgrading in developing countries.

It is further argued that the effects of international activities on the demand for skilled labor vary from country to country [4]. In the comparative case study of Brazil and China, Fajnzylber and Fernandes obtained opposite results between the two countries, namely, Brazil increased in the demand for skilled labor while China increased in the employment of unskilled labor. The reasons go beyond the endowments of fundamental factors and lie in national absorptive capacities, which are related to institutional setting, labor skills, technological capabilities, and the competitiveness of domestic firms, all of which have an effect of globalization on skill upgrading in a specific country [3]. The prosperity of export-oriented and labor-intensive industries provided RUMWs with many job opportunities with low levels of skill and income, but few opportunities for skill accumulation [15]. It is reported that RUMWs have been exposed to unpleasant or even unhealthy work conditions with overtime work and less leisure, and have little time to attend continuing education or cannot afford professional training [41]. Lacking in skill accumulation, a structured labor shortage has emerged with the increasing demand for skilled workers, and, under these circumstances, labor-intensive industries have been transferred into other neighboring LDCs [16]. 


\subsubsection{Innovation, Openness, and Skill Upgrading}

Innovation is believed to have a strong skill-bias [42], that is to say, innovation and skill intensity usually complement one another. Empirical studies confirm that firms doing R\&D (R\&D is usually taken as an important type of innovative activity) have a higher demand for skilled labor [4], and R\&D expenditures are positively and significantly related to skill upgrading in some middle income countries [36].

It is argued that innovation in developing countries is inherently connected with trade, FDI, and a consequent international transfer of technology [42]. Salomon and Shaver (2005) proposed a "learning by exports" hypothesis (LEH) and argued that access to foreign markets provides exporting firms with feedback from their foreign partners, which is useful for their internal innovation [43]. Wagner put forward a self-selection hypothesis (SSH), which argues that export firms have superior performance characteristics compared to non-export firms [44]. Actually, the characteristics of a firm, such as firm size and age, are an important determinant of its international activities, and the latter in turn affects the employment and labor type as analyzed before. Moreover, the level of education of a firm's management is an important determinant of skilled labor demand [4]. Further evidence shows that LEH is beneficial for groups of young firms, while SSH has been proven relevant for groups of mature firms [45]. This means that domestic firms benefit from foreign firms unequally. It has been argued that spillovers from foreign firms are determined by the technological profiles, embeddedness and linkage creation of both foreign and domestic firms [46]. In addition, firms' introduction of new product lines or adoption of foreign technology are not necessarily related to skill upgrading, for other attributes, such as financial constraints and managerial ability, affect a firm's ability to attract more skilled labor [47].

Openness and lowering trade barriers increase foreign competition and force domestic firms to make technological and product innovation, in order to decrease the production cost or reduce the substitutability of their products $[46,48]$. Consequently, the demand for highly skilled labor is supposed to increase. However, the extant literature pays more attention to the effects of firm innovation on skill demand than to its effect on the promotion of laborers' skill accumulation. With the acceleration of technological progress and intensification of international competition, firms in LDCs are making a strategic transformation from a low-cost-based strategy that relies on large-scale manufacturing technologies to a differentiation-oriented strategy that depends on technological innovation and flexible manufacturing system with high efficiency [49]. In Pine's (1993) view, the low-cost strategy emphasizes operational efficiency, and workers are only a part of the production process. In this production system, workers are not required to be innovative; they are trained just to engage in standardized and simple labor. It is difficult for them to obtain opportunities for skill accumulation or upgrading. On the contrary, the differentiation strategy emphasizes process efficiency, pays attention to the improvement of workers' learning ability and creativity, and encourages them to make continual enhancement and improvement of the production process and overall efficiency [50]. For this reason, firms not only provide more opportunities for education and skill training but also advocate "learning by doing" and "team learning", which has promoted workers' skill accumulation to a certain extent [51]. In particular, "learning by doing" has been discovered as an effective approach for Chinese RUMWs to accumulate skills and experience, thus lightening the payment restrictions of human capital investment [8]. However, whereas the relevant literature concerns itself greatly with the relations between skill upgrading, technological innovation, and firm characteristics, as mentioned above, it also fails to pay attention to the effects of such intra-firm skill-biased strategies on RUMWs' skill accumulation.

The authors define the behaviors of firms emphasizing and utilizing workers' skills and creativity as skill preference and assume that such preference would promote RUMWs' skill accumulation by providing them with training and other incentive measures. Based on the analysis conducted above, the skill preference of firms in efficiency improvement is measured from three aspects, namely, provision of on-the-job training, encouragement of "learning by doing", and encouragement of "team learning". Thus, the following hypothesis is put forward:

Hypothesis $\mathbf{1}$ (H1). The skill preference of a firm is positively correlated with RUMWs' skill accumulation. 


\subsection{Localization and Skill Upgrading}

As mentioned above, the effects of international trade/globalization on skill upgrading to some extent depend on the country or region itself, such as national absorptive capability [3], domestic capabilities [52], or local assets and strategies [38]. The international trade literature has little discussion of the effects of localization on skill upgrading, but industrial clusters research considers that clustering conditions, which are based on the two important factors of intensive inter-firm/personal relationships and institutional thickness, are the source of regional competitiveness or advantage [53], and that it is important for individuals or firms to gain access to external knowledge for innovation or skill accumulation through interactive learning [54].

\subsubsection{Inter-Firm Relationships and RUMWs' Skill Accumulation}

Inter-firm relationships contain informal interpersonal relationships and formal cooperative, competitive and controlling partnerships among local firms, such as input-output linkages, technical connections and the bargaining power between firms. Cooperation among competitors in the provision of industry-specific skills is beneficial to establish training standards and also lowers the costs of investment in skills and information sharing [55]. Such relationships can improve a firm's innovation capability [56-59] and are the source of "collective efficiency" [60], i.e., competitive advantage generated by the local external economy and joint action. Firstly, firms of the same trade have similar worker skill demands. This benefits workers to stably and continuously make skill investments and leads to the formation of a labor team with professional skills. Human capital serves pricing and rewards skills [21]. Industrial access and promotion space influence the vocational development opportunities of RUMWs. These local market environments have a certain effect on the return on the human capital investment of RUMWs [28], influencing the growth of human capital. Secondly, the geographical agglomeration of firms of the same trade also makes it convenient for workers to acquire technologies, knowledge and information through approaches such as personnel flow and interpersonal relations, thus increasing the opportunities to learn skills. Thirdly, inter-firm cooperation is accompanied by personnel flow and information communication. The effects of knowledge transfer are influenced by the social relationship between dispatched technical personnel and employees of technical receiving firms, increasing for employees of these enterprises the opportunities to learn, communicate, or train cooperative firms [61,62]. Furthermore, in order to control product quality, local leading firms usually select and assign technical personnel to conduct quality supervision of contracted firms and to provide necessary technical training and guidance. The degree of severity of the requirement of leading firms for quality specification urges contracted firms to enhance technological innovation and quality management, and finally promotes the extension of product supply cooperation to technical R\&D cooperation between downstream supplies and upstream customers. The one-sided technical output is transformed into a two-way technical communication, promoting the growth of human capital for employees of the firms of both parties [63]. The first two points are related to the external economy, while the second two points involve inter-firm joint action.

In this paper, the authors consider enterprise cooperation or control on a regional scale instead of on a global scale. Enterprise cooperation or control in this regard reflects the collective efficiency of local production organizations, and discusses whether such a relationship has a significant influence on RUMWs' skill upgrading. The following hypothesis is put forward which refers to the relevant research and selects certain aspects, such as enterprise cooperation, enterprise competition and the local labor market, to measure inter-firm collective efficiency (factor selection is shown in Section 4):

Hypothesis 2 (H2). Collective efficiency among local firms is positively correlated with RUMWs' skill accumulation. 


\subsubsection{Institutional Thickness, Non-Firm Relations, and Skill Upgrading of RUMWs}

Institutional thickness is used to describe how localized institutional conditions (including the strong presence of local institutions such as firms, government agencies, training centers, research institutions, business associations, communities, etc.) and the strength of shared rules, conventions, and knowledge, can promote regional economic success [53]. As investors for human growth of laborers [1], these intermediary institutions limit the detrimental effects of market failures [55]. The high levels of close interaction and coalition amongst many diverse institutions [64,65] produces a high innovative capacity [66] and can promote knowledge diffusion between firms and knowledge-intensive institutions [65]. The relationship of RUMWs with these organizations may be direct individual-organization contact, or an indirect, inter-organizational connection through the firms the RUMWs work in.

\section{Government}

As an investor in human capital, local governments improve RUMWs' skill accumulation through human resources development projects, institutional environment design, and public services/facilities [28]. With the increasingly serious scarcity of skilled labor and the great concern of the central government regarding RUMWs' human capital, local governments are beginning to pay more attention to improving the life and employment circumstances of the floating population.

\section{NGOs}

NGOs targeted at RUMWs have emerged in China since the late 1990s. They mainly help RUMWs receive legal assistance, maintain their legitimate rights and interests, and collaborate with local government, firms, training organizations, and volunteers to raise funds and provide training services for RUMWs [29]. However, due to disputes over the legality of their identities, some NGOs are lacking in adequate resources, and encounter difficulties in obtaining government support. Their effects on RUMWs' skill accumulation are not yet significant.

\section{Vocational Training Organizations (VTOs)}

Vocational education and training is considered an alternative to regular academic education and meets the RUMWs' demands of career development in China [30]. These organizations provide professional knowledge and skill training to improve RUMWs' employability and enhance their willingness for self-learning [67]. However, doubts have arisen from the fact that a large number of VTOs provide low-level skill training which does not meet the demands of firms, and that the training fees are too high for RUMWs.

\section{Labor Unions}

Labor unions play an important role in improving workers' welfare, policy consulting, labor legislation, and the supervision and coordination of labor-management relations in China. With regard to skill accumulation, labor unions provide workers with employment information and vocational training by establishing service agencies such as employment and training agencies [68]. In addition, through communication with firms and training organizations, labor unions arrange well-targeted training programs for employees to improve their vocational skills. However, the extant literature has little mention of whether RUMWs can be involved in local labor unions and thereby obtain opportunities for skill accumulation.

\section{Rural-Urban Migrant Communities}

As informal organizations, rural-urban migrant communities contain intensive personal relationships and are indispensable to RUMWs' daily life and career development. These communities not only solve accommodation problems, but also provide employment information, offer job opportunities, safeguard economic interests of RUMWs and solve labor-capital disputes. Moreover, 
social relationships based on similar career experience as RUMWs or fellow townsman associations also provide RUMWs with platforms to share sensitive information and advice, learn skills, and enhance their ability to negotiate with firms to realize increases in income and improvements in work and living conditions $[59,69]$. However, due to a lack of elites, such communities have a limited effect on the improvement of RUMWs' human capital.

In summary, only when local non-firm organizations can provide skill-related services will RUMWs obtain opportunities that promote skill accumulation. The authors borrow the concept of "accessibility" to represent the possibility or convenience of establishing contacts with non-firm organizations and thereby acquiring relevant services (including regulations and policies formulated by local governments) to put forward the following hypothesis:

Hypothesis 3 (H3). Accessibility of local non-firm institutions is positively correlated with RUMWs' skill accumulation.

\section{Research Areas and Data Collection}

\subsection{Research Areas}

This paper selects Suzhou City, Jiangsu Province and Taizhou City, Zhejiang Province located in the Yangtze River Delta in the east of China as research areas (see Figure 1) for the following reasons. Firstly, the Yangtze River Delta is one of the manufacturing agglomerations of China, and two rural industrialization models, namely, "South Jiangsu Model" and "Wenzhou Model" emerged in the late 1970s when China implemented a planned economy. The two models represent different means of rural industrialization in China in the late 1970s. The "South Jiangsu Model" originated from the southern area of Jiangsu Province in the 1960s, including Suzhou, Wuxi, Changzhou, Yixing, Zhenjiang, and Nanjing. Local rural communes or production teams built up firms with collective ownership, promoted the development of the local economy, and speeded up the process of industrialization in rural areas. The "Wenzhou Model" also emerged at the same time, but relied on family-owned factories and used local rural markets to invigorate circulation channels and to promote the level of local industrialization [70]. Suzhou and Taizhou are typical regions of these two respective models. Secondly, in recent years, these two models have been undergoing dramatic changes. South Jiangsu has developed into the transfer destination of international industries and has become home to abundant foreign-funded firms. Suzhou Industrial Park (SIP) is viewed as a typical example of the "New South Jiangsu Model" [71]. The Wenzhou Model has quickly spread to its neighboring regions (especially adjacent Taizhou) and entered the era of the "Wenzhou-Taizhou Model". Based on the location advantage of geographical adjacency with Wenzhou (see Figure 1), Yuhuan County of Taizhou has become a region that has benefited from the industrial outflow of Wenzhou in relatively early stages, and is a representative region of the "Wenzhou-Taizhou Model". A group of family-owned firms has endeavored to make the transformation to modern corporations and blend into global production networks mainly through foreign trade, but, in general, they rely on the international market less than those firms in Suzhou. The permanent resident population of Yuhuan County is equivalent to that in SIP. Its gross regional production and industrial added value are both near 1/5 of those in SIP, but its economic indexes concerning foreign trade and foreign investment are far lower than those in SIP (see Table 1). Thirdly, both research areas are conglomeration places of RUMWs, who used to sustain local development and reshape local competitive advantage through skill upgrading. The data obtained from the sixth demographic census indicate that the floating population of SIP approached $50 \%$ of the permanent population in 2010 , while that of Yuhuan reached $38 \%$. 


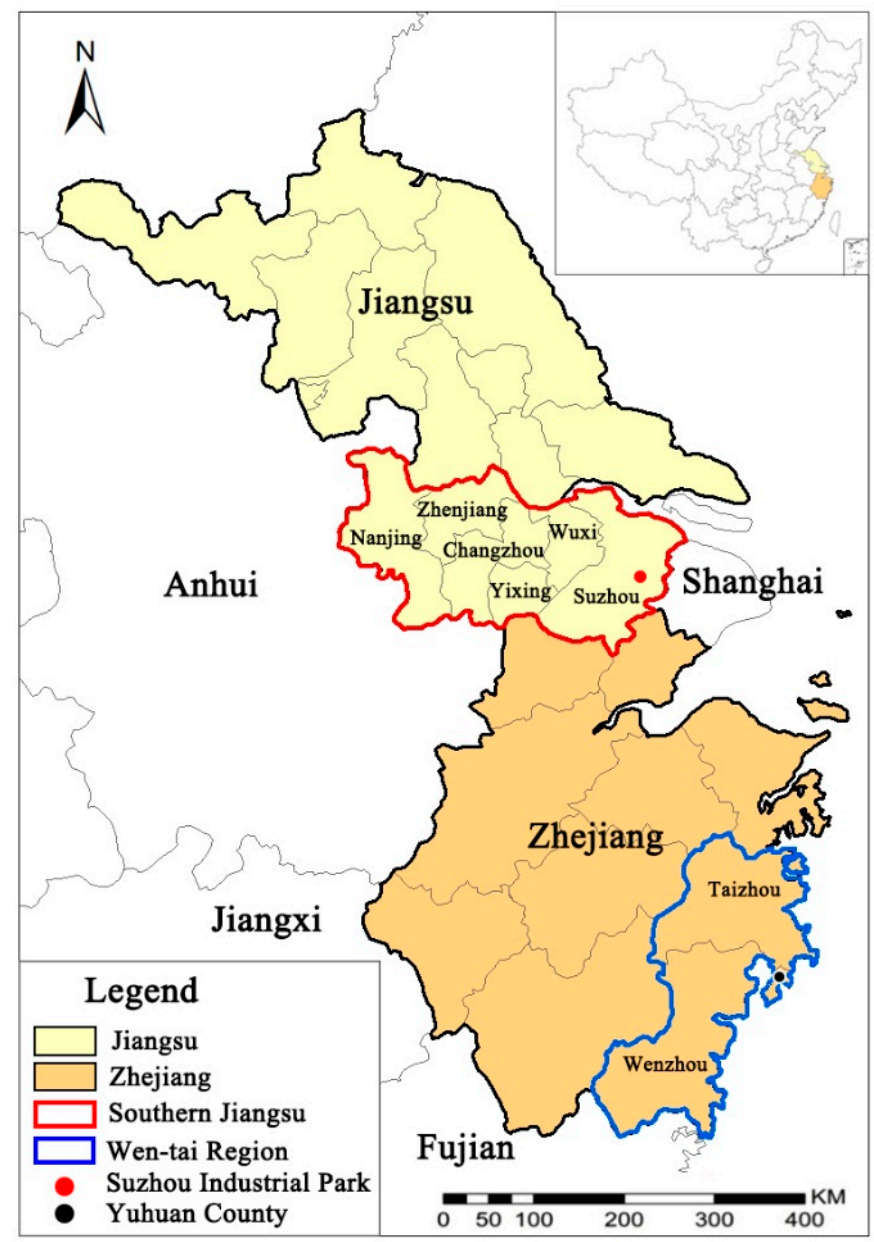

Figure 1. Geographical Location of Research Areas.

Table 1. Main Social and Economic Indexes in SIP and Yuhuan in 2014.

\begin{tabular}{|c|c|c|c|}
\hline & SIP & Yuhuan & SIP:Yuhuan \\
\hline Permanent resident population $(10,000$ persons $)$ * & 69.53 & 61.63 & 1.13:1 \\
\hline Gross Regional Production (GRP, 100 million RMB) & 2059.95 & 438.67 & $4.70: 1$ \\
\hline Industrial added value (100 million RMB) & 1111.71 & 226.85 & $4.90: 1$ \\
\hline Fixed-asset investment (100 million RMB) & 611.82 & 163.55 & $3.74: 1$ \\
\hline Regional gross import (100 million USD) & 390.84 & 1.05 & 372.22:1 \\
\hline Regional gross export (100 million USD) & 405.12 & 34.09 & 11.88:1 \\
\hline Ratio of net export in regional GRP & $0.7 \%$ & $7.5 \%$ & 0.09:1 \\
\hline Foreign investment in actual use (USD 100 million) & 16.00 & 0.11 & $145.45: 1$ \\
\hline $\begin{array}{l}\text { Number of foreign-invested and Hong Kong, Macao and } \\
\text { Taiwan industrial firms above designated size }\end{array}$ & 693 & 51 & 13.59:1 \\
\hline Number of private industrial firms above designated size ${ }^{* *}$ & 113 & 705 & $0.16: 1$ \\
\hline
\end{tabular}

Notes: (1)* These data were obtained from the main data bulletin of the sixth demographic census in 2010;

(2) ** These data were obtained from statistical yearbooks of Suzhou and Taizhou in 2015; (3) Other data were obtained from the statistical data of Suzhou Industrial Park in 2015 and statistical bulletins of national economic and social development of Yuhuan County in 2015. 


\subsection{Questionnaire Survey}

The authors adopted a structured questionnaire survey for first-hand data collection. The questionnaire covers RUMWs' basic information, work changes before and after migration, vocational skills accumulation, the nature of the firm they work for, its competition and cooperation with other firms, employee training and incentives, local policies, cultural facilities, and skill training services from relevant organizations, etc. The survey was successively conducted in SIP and Yuhuan County from July to September 2015. As RUMWs need to go through 3-6 months of apprenticeship or internship after entering into firms, this survey selected those RUMWs who have worked in SIP or Yuhuan for at least more than half a year. It was difficult to get permission for the survey inside a firm in both research areas. The authors learned from local residents the conglomeration places where RUMWs live, dine, seek entertainment, and go shopping, and then launched the survey. In order to avoid the little coverage of questionnaires in a handful of firms, only one RUMW was selected each time among the RUMWs with the same type of work or position in the same firm.

The authors issued 700 questionnaires and recovered 668 questionnaires in the two areas in total, and 491 of those 668 questionnaires were valid with a validity rate of $73.5 \%$. The invalid questionnaires had blank responses or respondents who had worked in SIP or Yuhuan less than half a year. In SIP, the authors issued 400 questionnaires and recovered 388 questionnaires with a recovery rate of $97 \%$. There were 235 valid questionnaires with a validity rate of $60.56 \%$. In Yuhuan, the authors issued 300 questionnaires in total and recovered 280 questionnaires with a recovery rate of $93.33 \%$. There were 256 valid questionnaires with a validity rate of $91.43 \%$. In SIP, many respondents had worked less than half a year, while only a few respondents could not meet the requirement of working time in Yuhuan, which led to the differences in the validity rates of the two areas.

\subsection{Characteristics of Effective Samples}

The basic information from effective samples is shown in Table 2. In summary, these samples generally have the following characteristics:

\subsubsection{Demographic Characteristics}

Among the total samples, the proportion of male to female is 7:3. Compared with Yuhuan, SIP had more male samples. According to the survey, SIP focuses on electronic product processing and manufacturing and machinery manufacturing, which need more male workers. The number of new-generation RUMWs aged below 35 makes up approximately $88 \%$ of the total samples; compared with Yuhuan, the age structure of RUMWs in Suzhou is younger.

The number of unmarried migrants in the total samples is higher than that of married migrants. The ratio between married migrants and unmarried migrants reaches 6:4 in Yuhuan, while this ratio in SIP is nearly 3:7.

The RUMWs surveyed mainly have an educational background of secondary school, making up $77.2 \%$ of the total. Those with an educational background of junior high school make up about one third of the total, while those with an education background of senior high school, professional high school, and technical secondary school exceed $40 \%$ of the total survey respondents. Compared with SIP, the RUMWs surveyed in Yuhuan have a relatively low educational background, and those with educational background of junior high school and below make up $55.47 \%$, which is $38 \%$ higher than those in SIP. In terms of the survey, the firms in SIP are mostly foreign-funded and have relatively high requirements for the initial education level of their employees; whereas most privately-owned firms or family-owned workshops in Yuhuan have relatively low requirements. 


\subsubsection{Conditions of Occupations and Skills before and after Migrant Work}

More than $1 / 3$ of the RUMWs surveyed were in-school students before migration; $27.3 \%$ were engaged in agriculture before migration; $23.8 \%$ of them worked in a firm previously; and $26.68 \%$ had worked in the immigrating place for 1-3 years, $21.59 \%$ had worked there for $3-5$ years, and $20 \%$ had worked there for 5-10 years. Compared with Yuhuan, the length of the RUMWs surveyed migration to Suzhou is generally short. The RUMWs with length of service above five years in SIP make up $19.57 \%$, 9.55\% lower than that in Yuhuan. About $80 \%$ of the RUMWs surveyed were ordinary workers and about $10 \%$ of them were group leaders. More than half of the RUMWs surveyed had no vocational skill qualification certificates. With regard to this index, the situation in SIP is much better than that in Yuhuan.

Table 2. Basic Information of Valid Samples in SIP and Yuhuan.

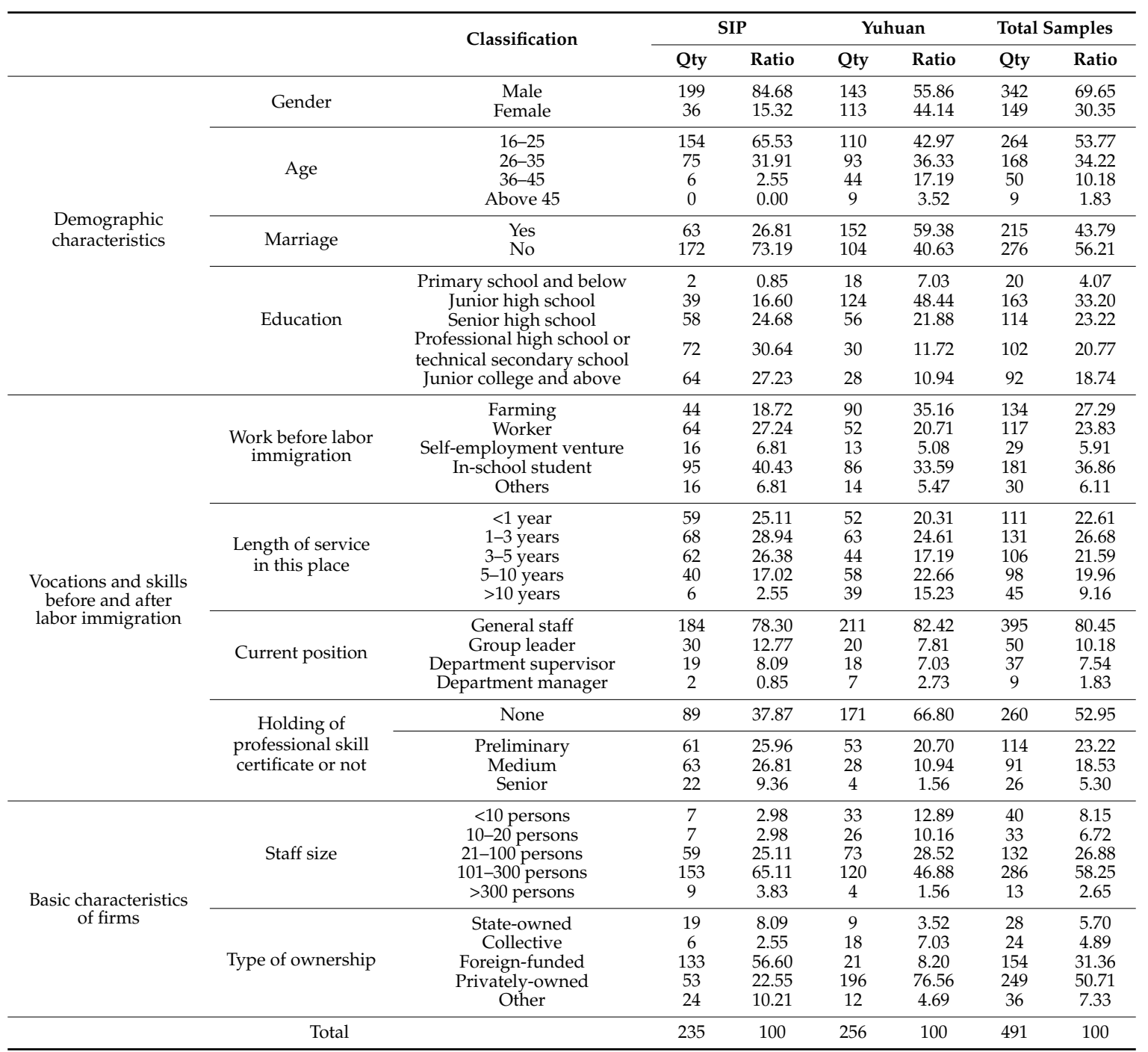

Note: "Junior college and above" does not include RUMWs with previous undergraduate and postgraduate education.

\subsubsection{Characteristics of the Firms for Which the RUMWs Surveyed Work}

In total, $58.25 \%$ of the RUMWs surveyed worked in medium-sized firms with 101-300 employees (according to national standard of firm scale), and $26.88 \%$ of them worked in small firms with 21-100 employees. Almost half of the firms RUMWs surveyed worked for in Yuhuan were small-scale firms with no more than 100 employees, while nearly $70 \%$ of the firms in SIP were large 
and medium-sized. Furthermore, most of the firms for which the RUMWs surveyed worked for in SIP are foreign-funded or joint-ventures-funded, while Yuhuan is dominated by private firms and undergoing the transformation of traditional industries.

\section{Selection of Variables and Model and Analysis of Results}

\subsection{Selection and Measurement of Variables}

The International Labor Organization categorizes skills into four aspects, namely, basic skills, core work skills, technical or vocational ability, and entrepreneur and operation management capacity. Basic skills refer to basic language and computing power as well as the application of such capacities in specific environments, work skills refers to a general capacity increasing the possibility of employment in the labor market, and technical and vocational ability means the ability enabling individuals to complete specific tasks, such as carpentry, basket fabrication, metal work, forging, etc. [72]. This research defines RUMWs' skills as "vocational ability", and uses "skill accumulation" as a dependent variable, which is specifically interpreted in the questionnaire as the "improvement of vocational skills after migration to current place". The respondents could make a judgment based on their own condition, including the acquisition of a vocational qualification certificate, promotion of working post grade, and income increase due to skill accumulation. The Likert 5-score method is adopted for assignment (detailed in Table 3 below).

Three independent variables, namely, "firm attributes and skill preference", "collective efficiency" and "accessibility of non-firm institutions", containing 15 variables in total, are selected. Individual attributes are used as control variables. Meanwhile, "regional factor" is introduced as a control variable to examine whether or not the two research areas have any differences in RUMWs' skill accumulation. The names of each variable, selection basis, meaning and method of measurement are shown in Table 3 .

\subsection{Model Selection and Results}

Based on the related data of 491 valid samples, the authors used ordered logistic regression models, as the dependent variable "skill accumulation" has five-ordered categories [73], to estimate the impact of three independent factors on RUMWs' skill accumulation, with the factors of "regional factor" and "individual factors" used as control variables in the three models. A correlation matrix of the independent and control variables is shown in Table 4 . There is no multi-collinearity of variables as the variance inflation factor (VIF) scores are under 10, so the regression models are not distorted by this problem [73].

Models I, II, and III are set up to discuss the relationships between RUMWs' skill accumulation and three kinds of factors, namely "firm attributes and skill preference", "collective efficiency", and "accessibility of non-firm institutions", respectively. All variables are involved in Model IV to discuss which variables influence RUMWs' skill accumulation when all factors are considered. The results are shown in Table 5. All models present a good fit, as models' chi-squares are significant at the 0.01 level, the test of parallel line could not reject the null hypothesis $(p>0.05)$, and the Pearson chi-square of goodness-of-fit measure are non-significant $(p>0.05)$. 
Table 3. Selection of Factors and Indexes Influencing Skill Accumulation of New-generation RUMWs.

\begin{tabular}{|c|c|c|c|c|}
\hline Factor & Variable & Name & Description of Meaning/Definition & Quantitative Criteria \\
\hline Dependent variable & $\mathrm{Y}$ & Skill accumulation & Significant improvement of vocational skills & $\begin{array}{l}5 \text { for "Strongly Agree"; } \\
4 \text { for "Relatively Agree"; } \\
3 \text { for "Generally Agree"; } \\
2 \text { for "Relatively Disagree"; } \\
1 \text { for "Strongly Disagree" }\end{array}$ \\
\hline Regional factor & RG & City & - & 1 for Yuhuan; 0 for SIP \\
\hline \multirow{4}{*}{ Individual factors } & ID1 & Gender [24] & - & 1 for male; 0 for female \\
\hline & ID2 & Education [23] & Education level before migrant work & $\begin{array}{l}1 \text { for primary school and below; } \\
2 \text { for junior high school; } \\
3 \text { for regular senior high school; } \\
4 \text { for professional high school or } \\
\text { technical secondary school; } \\
5 \text { for junior college and above }\end{array}$ \\
\hline & ID3 & Length of service [27] & Length of RUMWs' service in the migrating place & $\begin{array}{l}1 \text { for less than } 1 \text { year; } \\
2 \text { for } 1-3 \text { years; } \\
3 \text { for } 3-5 \text { years; } \\
4 \text { for } 5-10 \text { years; } \\
5 \text { for more than } 10 \text { years }\end{array}$ \\
\hline & ID4 & Self selection [18] & $\begin{array}{l}\text { Labors chose the firm they currently work in } \\
\text { mainly for the pursuit of skill accumulation }\end{array}$ & $\begin{array}{l}1 \text { for choosing firms for skill accumulation; } \\
0 \text { for choosing firms for other reasons }\end{array}$ \\
\hline \multirow{6}{*}{$\begin{array}{l}\text { Firm attributes and } \\
\text { skill preference }\end{array}$} & INFC1 & Firm size [73] & Number of employees of the firm RUMWs work for & $\begin{array}{l}1 \text { for }<10 \text { employees; } \\
2 \text { for 10 20 employees; } \\
3 \text { for 21 100 employees; } \\
4 \text { for 101 300 employees; } \\
5 \text { for }>300 \text { employees }\end{array}$ \\
\hline & INFC2 & Firm ownership [74] & The ownership of the firm RUMWs work for & $\begin{array}{l}1 \text { for state-owned; } \\
2 \text { for privately-owned; } \\
3 \text { for foreign-owned }\end{array}$ \\
\hline & INFC3 & International trading [5] & The trading of the firm RUMWs work for & $\begin{array}{l}1 \text { for having import and export trades; } \\
0 \text { for not having import and export trades }\end{array}$ \\
\hline & INFC4 & On-the-job training [49] & The firm often provides employees with on-the-job skill training. & \multirow{3}{*}{$\begin{array}{l}\text { Likert scale method is adopted. Scoring is } \\
\text { implemented according to the agreeing degrees: } \\
5 \text { for "Strongly Agree"; } \\
4 \text { for "Relatively Agree"; } \\
3 \text { for "Generally Agree"; } \\
2 \text { for "Relatively Disagree"; } \\
1 \text { for "Strongly Disagree". }\end{array}$} \\
\hline & INFC5 & Encouragement of "learning by doing" [27] & The firm encourages "learning by doing" to improve employees' skills. & \\
\hline & INFC6 & Encouragement of "team learning" [51] & $\begin{array}{l}\text { The firm encourages its employees to learn } \\
\text { from their colleagues to improve their skills. }\end{array}$ & \\
\hline
\end{tabular}


Table 3. Cont

\begin{tabular}{|c|c|c|c|c|}
\hline Factor & Variable & Name & Description of Meaning/Definition & Quantitative Criteria \\
\hline \multirow{4}{*}{ Collective efficiency } & ITFC1 & Inter-firm cooperation [61] & $\begin{array}{l}\text { There are many local firms of the same trade and the economic } \\
\text { and technical cooperation is frequent. }\end{array}$ & \multirow{9}{*}{$\begin{array}{l}\text { Likert scale method is adopted. Scoring is } \\
\text { implemented according to the agreeing degrees } \\
5 \text { for "Strongly Agree"; } \\
4 \text { for "Relatively Agree"; } \\
3 \text { for "Generally Agree"; } \\
2 \text { for "Relatively Disagree"; } \\
1 \text { for "Strongly Disagree". }\end{array}$} \\
\hline & ITFC2 & Inter-firm competition [62] & $\begin{array}{l}\text { Local firms of the same trade often } \\
\text { compete for technical workers. }\end{array}$ & \\
\hline & ITFC3 & Job opportunity [28] & $\begin{array}{l}\text { Local job opportunities for RUMWs } \\
\text { with higher vocational skills increase. }\end{array}$ & \\
\hline & ITFC4 & Local skill demand [23] & $\begin{array}{l}\text { The local requirements for vocational } \\
\text { skills of RUMWs are generally raised. }\end{array}$ & \\
\hline \multirow{5}{*}{$\begin{array}{l}\text { Accessibility of } \\
\text { Non-firm institutions }\end{array}$} & NFR1 & Supply of public cultural facilities [33] & $\begin{array}{l}\text { Local cultural facilities can be utilized to improve individuals' } \\
\text { education level or vocational ability. }\end{array}$ & \\
\hline & NFR2 & Government incentive policy [75] & $\begin{array}{l}\text { Those with sufficient educational background or certain } \\
\text { vocational technical qualification certificates can easily obtain } \\
\text { local permanent registered residence. }\end{array}$ & \\
\hline & NFR3 & NGO [29] & There are local NGOs improving vocational skills of RUMWs. & \\
\hline & NFR4 & Vocational training organization [67] & $\begin{array}{l}\text { There are local private organizations providing } \\
\text { vocational skill training for RUMWs. }\end{array}$ & \\
\hline & NFR5 & Fellow townsman community [69] & $\begin{array}{l}\text { Fellow townsmen working in different firms can often learn } \\
\text { from each other to improve their vocational skills. }\end{array}$ & \\
\hline
\end{tabular}


Table 4. Descriptive Statistic and Correlation Matrix of Independent Variables.

\begin{tabular}{|c|c|c|c|c|c|c|c|c|c|c|c|c|}
\hline Variables & VIF & Mean & SD & RG & ID1 & ID2-PS & ID2-JHS & ID2-RSHS & ID2-PHS & ID3 & ID4 & INFC1 \\
\hline RG & 1.71 & 0.52 & 0.50 & 1.00 & & & & & & & & \\
\hline ID1 & 1.18 & 0.70 & 0.46 & $-0.31^{* * *}$ & 1.00 & & & & & & & \\
\hline ID2-PS & 1.40 & 0.04 & 0.20 & $0.16^{* * *}$ & $-0.07 *$ & 1.00 & & & & & & \\
\hline ID2-JHS & 2.49 & 0.35 & 0.48 & $0.38^{* * *}$ & $-0.25^{* * *}$ & $-0.15^{* * *}$ & 1.00 & & & & & \\
\hline ID2-RSHS & 1.82 & 0.21 & 0.41 & $-0.07 *$ & $0.08^{* *}$ & $-0.11^{* * *}$ & $-0.38^{* * *}$ & 1.00 & & & & \\
\hline ID2-PHS & 1.79 & 0.21 & 0.41 & $-0.25^{* * *}$ & $0.06^{*}$ & $-0.11^{* * *}$ & $-0.38^{* * *}$ & $-0.26^{* * *}$ & 1.00 & & & \\
\hline ID3 & 1.18 & 2.66 & 1.28 & $0.17^{* * *}$ & -0.01 & $0.14^{* * *}$ & $0.16^{* * *}$ & 0.00 & -0.04 & 1.00 & & \\
\hline ID4 & 1.17 & 0.29 & 0.46 & $0.09^{* *}$ & 0.00 & 0.03 & 0.04 & -0.01 & -0.04 & -0.06 * & 1.00 & \\
\hline INFC1 & 3.03 & 3.34 & 0.93 & $-0.26^{* * *}$ & 0.07 * & $-0.19^{* * *}$ & $-0.09 * *$ & 0.01 & $0.07^{*}$ & -0.02 & $-0.26^{* * *}$ & 1.00 \\
\hline INFC2-G & 1.51 & 0.11 & 0.31 & 0.00 & -0.02 & 0.03 & 0.04 & -0.02 & -0.03 & -0.03 & $0.14^{* * *}$ & -0.06 \\
\hline INFC2-M & 2.15 & 0.59 & 0.49 & $0.47^{* * *}$ & $-0.16^{* * *}$ & $0.11^{* * *}$ & $0.16^{* * *}$ & -0.05 & $-0.13^{* * *}$ & $0.16^{* * *}$ & -0.03 & $-0.24^{* * *}$ \\
\hline INFC3 & 3.38 & 0.64 & 0.48 & $-0.29^{* * *}$ & $0.07^{*}$ & $-0.10^{* *}$ & $-0.13^{* * *}$ & -0.01 & $0.09 * *$ & $-0.07 *$ & $-0.20^{* * *}$ & $0.79^{* * *}$ \\
\hline INFC4 & 1.25 & 3.10 & 1.56 & $-0.12^{* * *}$ & 0.05 & -0.05 & $-0.10^{* *}$ & 0.01 & 0.00 & $-0.18^{* * *}$ & $0.15^{* * *}$ & -0.02 \\
\hline INFC5 & 1.34 & 3.52 & 0.96 & 0.07 * & 0.03 & 0.01 & 0.05 & -0.02 & -0.02 & 0.02 & 0.05 & $-0.10^{* *}$ \\
\hline INFC6 & 1.11 & 3.18 & 1.29 & -0.01 & 0.00 & -0.02 & -0.06 & -0.01 & 0.03 & -0.02 & 0.01 & 0.04 \\
\hline ITFC1 & 1.39 & 3.47 & 0.97 & 0.02 & -0.01 & -0.01 & 0.03 & -0.04 & -0.03 & 0.05 & $0.13^{* * *}$ & -0.04 \\
\hline ITFC2 & 1.13 & 3.55 & 1.06 & 0.00 & 0.03 & $-0.06^{*}$ & -0.03 & 0.03 & 0.04 & 0.02 & $0.11^{* * *}$ & -0.05 \\
\hline ITFC3 & 1.26 & 3.79 & 0.96 & -0.05 & -0.01 & -0.06 * & -0.04 & 0.00 & 0.01 & 0.04 & 0.00 & $-0.06^{*}$ \\
\hline ITFC4 & 1.33 & 3.54 & 1.01 & 0.04 & 0.02 & -0.01 & 0.04 & -0.04 & 0.01 & 0.05 & $0.09^{* *}$ & $-0.06^{*}$ \\
\hline NFR1 & 1.51 & 3.52 & 1.04 & -0.01 & -0.05 & $-0.07 *$ & 0.07 * & $-0.07^{*}$ & -0.01 & -0.05 & 0.07 * & $-0.10^{* *}$ \\
\hline NFR2 & 1.40 & 2.92 & 1.20 & -0.01 & 0.04 & 0.07 * & -0.03 & -0.01 & -0.05 & -0.05 & $0.15^{* * *}$ & $-0.09^{* *}$ \\
\hline NFR3 & 1.75 & 3.37 & 1.05 & $-0.06^{*}$ & 0.03 & 0.03 & $-0.12^{* * *}$ & -0.04 & $0.06^{*}$ & -0.03 & $0.12^{* * *}$ & -0.06 * \\
\hline NFR4 & 1.92 & 3.30 & 1.07 & -0.06 & 0.03 & -0.01 & $-0.10 * *$ & -0.04 & 0.01 & 0.04 & $0.15^{* * *}$ & $-0.14^{* * *}$ \\
\hline NFR5 & 1.13 & 2.91 & 1.11 & $0.10^{* *}$ & 0.01 & -0.04 & 0.04 & -0.01 & -0.02 & 0.07 * & 0.04 & 0.02 \\
\hline
\end{tabular}


Table 4. Cont.

\begin{tabular}{|c|c|c|c|c|c|c|c|c|c|c|c|c|c|c|c|}
\hline Variables & INFC2-G & INFC2-M & INFC3 & INFC4 & INFC5 & INFC6 & ITFC1 & ITFC2 & ITFC3 & ITFC4 & NFR1 & NFR2 & NFR3 & NFR4 & NFR5 \\
\hline \multicolumn{16}{|l|}{$\begin{array}{l}\text { RG } \\
\text { ID1 }\end{array}$} \\
\hline \\
\hline \multirow{2}{*}{\multicolumn{16}{|c|}{$\begin{array}{l}\text { ID2--IHS } \\
\text { ID2-RSHS }\end{array}$}} \\
\hline & & & & & & & & & & & & & & & \\
\hline \multicolumn{16}{|l|}{ ID-2PHS } \\
\hline \multirow{2}{*}{\multicolumn{16}{|c|}{$\begin{array}{l}\text { ID3 } \\
\text { ID4 }\end{array}$}} \\
\hline & & & & & & & & & & & & & & & \\
\hline \multicolumn{16}{|l|}{$\begin{array}{l}\text { INFC1 } \\
\text { INFC }\end{array}$} \\
\hline INFC2-M & $-0.42 * * *$ & 100 & & & & & & & & & & & & & \\
\hline INFC3 & $-0.10 * *$ & $-0.40 * * *$ & 100 & & & & & & & & & & & & \\
\hline INFC4 & $0.14 * * *$ & $-0.21 * * *$ & $0.06^{*}$ & 1.00 & & & & & & & & & & & \\
\hline $\begin{array}{l}\text { INFC4 } \\
\text { INFC5 }\end{array}$ & 0.08 ** & $\begin{array}{c}-0.21 \\
0.03\end{array}$ & $-0.11 * * *$ & $0.14 * * *$ & 1.00 & & & & & & & & & & \\
\hline $\begin{array}{l}\text { INFCS } \\
\text { INFC6 }\end{array}$ & $\begin{array}{l}0.00 \\
-0.09 * *\end{array}$ & $\begin{array}{l}0.03 \\
0.02\end{array}$ & 0.04 & $0.14 * *$ & $-0.00 * *$ & & & & & & & & & & \\
\hline ITFC1 & $\begin{array}{l}-0.09 * * \\
0.09 *\end{array}$ & $\begin{array}{l}0.02 \\
-0.01\end{array}$ & $\begin{array}{l}0.04 \\
-0.03\end{array}$ & $0.18 * * *$ & $0.26 * * *$ & $\begin{array}{r}1.00 \\
-0.06 *\end{array}$ & 100 & & & & & & & & \\
\hline ITFC2 & $0.06 *$ & $\begin{array}{l}-0.01 \\
-0.01\end{array}$ & $\begin{array}{l}-0.03 \\
-0.05\end{array}$ & 0.18 ** & $0.26 * * *$ & $\begin{array}{l}-0.06 \text { * } \\
-0.08 *\end{array}$ & $0.00 * * *$ & 100 & & & & & & & \\
\hline $\begin{array}{l}\text { ITFC } 3 \\
\text { ITFC3 }\end{array}$ & $0.12^{* * * *}$ & $\begin{array}{l}-0.01 \\
-0.01\end{array}$ & $\begin{array}{l}-0.05 \\
-0.06 *\end{array}$ & $0.07 *$ & $0.15 * * *$ & -0.08 & $0.19 * * *$ & $0.00 * *$ & 100 & & & & & & \\
\hline $\begin{array}{l}\text { IIFC } \\
\text { ITFC4 }\end{array}$ & $0.14 * * *$ & $\begin{array}{l}-0.01 \\
-0.03\end{array}$ & $\begin{array}{l}-0.06 \\
-0.05\end{array}$ & $0.073_{* * *}^{*}$ & $0.32 * * *$ & $\begin{array}{r}0.03 \\
-0.08 *\end{array}$ & $0.25 * * *$ & $0.188^{* * *}$ & $0.23 * * *$ & & & & & & \\
\hline NFR1 & $\begin{array}{l}0.14 \\
0.15 * * *\end{array}$ & -0.03 **** & $\begin{array}{l}-0.05 \\
-0.07 *\end{array}$ & $0.132 \% * *$ & $0.32 * * * *$ & $-0.088^{n}$ & $0.38 * * *$ & $0.20 * * *$ & $0.26 * * *$ & $\begin{array}{l}1.00 \\
025 * * *\end{array}$ & 100 & & & & \\
\hline NFR2 & $0.17 * * *$ & $\begin{array}{l}-0.11 \\
-0.14 * * *\end{array}$ & $\begin{array}{l}-0.07 \\
-0.03\end{array}$ & $0.19 * * *$ & $0.30^{* * *}$ & $\begin{array}{l}0.06 \\
-0.03\end{array}$ & 0.31 *** & $0.13^{* * *}$ & $0.25 * * *$ & $0.21 * * *$ & $0.24^{* * *}$ & 100 & & & \\
\hline NFR3 & 0.10 ** & -0.09 ** & -0.01 & 0.31 *** & $0.30^{* * *}$ & $0.08^{* *}$ & $0.32^{* * *}$ & $0.11^{\text {*** }}$ & $0.26^{* * *}$ & $0.29 * * *$ & $0.36^{* * *}$ & $0.37^{* * * *}$ & 1.00 & & \\
\hline NFR4 & $0.09 * *$ & $-0.07 *$ & $-0.07 *$ & $0.26^{* * *}$ & $0.19^{* * *}$ & $0.09 * *$ & $0.35 * * *$ & 0.09 ** & $0.26^{* * *}$ & $0.27^{* * *}$ & $0.49^{* * *}$ & $0.32 * * *$ & $0.57^{* * *}$ & 1.00 & \\
\hline NFR5 & -0.04 & $0.11^{* * *}$ & $-0.06 *$ & $-0.07 *$ & $0.07 *$ & $0.19^{* * *}$ & $-0.07^{* * *}$ & -0.02 & 0.02 & -0.01 & -0.01 & $-0.16^{* * *}$ & 0.00 & -0.02 & 1.00 \\
\hline
\end{tabular}

Note: ${ }^{* * *}, * *$, and ${ }^{*}$ indicate significance at the level of $0.01,0.05$ and 0.1 , respectively. VIF = variance inflation factor; SD = standard deviation; JC = junior college and above; PS = primary school and below; JHS = junior high school; RSHS = regular senior high school; PHS = professional high school or technical secondary school. 
Table 5. Ordered Logistic Regression Results on the Factors Influencing RUMWs' Skill Accumulation.

\begin{tabular}{|c|c|c|c|c|c|c|c|c|}
\hline \multirow{2}{*}{ Variables } & \multicolumn{2}{|c|}{ Model I } & \multicolumn{2}{|c|}{ Model II } & \multicolumn{2}{|c|}{ Model III } & \multicolumn{2}{|c|}{ Model IV } \\
\hline & Coef. (S.E.) & OR & Coef. (S.E.) & OR & Coef. (S.E.) & OR & Coef. (S.E.) & OR \\
\hline RG & $0.238^{* *}(0.119)$ & 1.269 & $0.301^{* *}(0.119)$ & 1.351 & $0.298^{* *}(0.125)$ & 1.347 & $0.360^{* *}(0.143)$ & 1.433 \\
\hline ID1 & $0.021(0.107)$ & 1.021 & $0.045(0.120)$ & 1.046 & $0.038(0.126)$ & 1.039 & $0.013(0.129)$ & 1.013 \\
\hline \multicolumn{9}{|l|}{ ID2 (Ref. JC) } \\
\hline PS & $-0.230(0.273)$ & 0.795 & $-0.274(0.302)$ & 0.760 & $-0.333(0.313)$ & 0.717 & $-0.180(0.336)$ & 0.835 \\
\hline JHS & $-0.148(0.149)$ & 0.862 & $-0.201(0.165)$ & 0.818 & $-0.120(0.176)$ & 0.887 & $-0.139(0.184)$ & 0.870 \\
\hline RSHS & $-0.095(0.151)$ & 0.909 & $-0.118(0.168)$ & 0.889 & $-0.049(0.177)$ & 0.952 & $-0.099(0.183)$ & 0.906 \\
\hline PHS & $-0.306^{* *}(0.148)$ & 0.736 & $-0.412 * *(0.164)$ & 0.662 & $-0.435^{* *}(0.171)$ & 0.647 & $-0.460^{* * *}(0.178)$ & 0.631 \\
\hline ID3 & $0.067^{*}(0.039)$ & 1.069 & $0.048(0.043)$ & 1.049 & $0.062(0.045)$ & 1.064 & $0.061(0.047)$ & 1.063 \\
\hline ID4 & $0.219 * *(0.109)$ & 1.245 & $0.246^{* *}(0.119)$ & 1.279 & $0.271^{* *}(0.125)$ & 1.311 & $0.236^{*}(0.135)$ & 1.266 \\
\hline INFC1 & $0.027(0.086)$ & 1.027 & & & & & $0.044(0.105)$ & 1.045 \\
\hline \multicolumn{9}{|c|}{ INFC2 (Ref. foreign-owned) } \\
\hline State-owned & $0.008(0.183)$ & 1.008 & & & & & $-0.035(0.224)$ & 0.966 \\
\hline Privately-owned & $-0.094(0.133)$ & 0.910 & & & & & $-0.141(0.160)$ & 0.868 \\
\hline INFC3 & $-0.088(0.176)$ & 0.916 & & & & & $-0.097(0.213)$ & 0.908 \\
\hline INFC4 & $0.060^{*}(0.031)$ & 1.062 & & & & & $0.091 * *(0.039)$ & 1.095 \\
\hline INFC5 & $0.179^{* * * *}(0.049)$ & 1.196 & & & & & $0.156^{* *}(0.065)$ & 1.169 \\
\hline INFC6 & $0.054(0.036)$ & 1.055 & & & & & $0.047(0.045)$ & 1.048 \\
\hline ITFC1 & & & $0.126^{* *}(0.058)$ & 1.134 & & & $0.097(0.065)$ & 1.102 \\
\hline ITFC2 & & & $0.129 * * *(0.049)$ & 1.138 & & & $0.171^{* * *}(0.054)$ & 1.186 \\
\hline ITFC3 & & & $0.108^{* *}(0.055)$ & 1.114 & & & $0.052(0.062)$ & 1.053 \\
\hline ITFC4 & & & $0.113 * *(0.055)$ & 1.120 & & & $0.081(0.061)$ & 1.084 \\
\hline NFR1 & & & & 1.120 & $0.126^{* *}(0.060)$ & 1.134 & $0.039(0.064)$ & 1.040 \\
\hline NFR2 & & & & & $0.072(0.050)$ & 1.075 & $-0.004(0.054)$ & 0.996 \\
\hline NFR3 & & & & & $0.056(0.063)$ & 1.058 & $-0.028(0.068)$ & 0.972 \\
\hline NFR4 & & & & & $0.118^{*}(0.067)$ & $\begin{array}{l}1.030 \\
1.125\end{array}$ & $0.117^{*}(0.071)$ & 1.124 \\
\hline NFR5 & & & & & $0.212^{* * *}(0.052)$ & 1.236 & $0.214^{* * *}(0.054)$ & 1.239 \\
\hline$Y=1$ & $-0.722^{*}(0.381)$ & 0.486 & $-0.206(0.346)$ & 0.814 & $-0.067(0.348)$ & 0.935 & $1.404 * *(0.545)$ & 4.071 \\
\hline$Y=2$ & $0.092(0.374)$ & 1.096 & $0.612^{*}(0.337)$ & 1.844 & $0.759^{* *}(0.337)$ & 2.136 & $2.251 * * *(0.540)$ & 9.497 \\
\hline$Y=3$ & $0.868^{* *}(0.373)$ & 2.382 & $1.480^{* * *}(0.335)$ & 4.393 & $1.666^{* * *}(0.336)$ & 5.291 & $3.227 * * *(0.543)$ & 25.204 \\
\hline$Y=4$ & $1.500^{* * *}(0.374)$ & 4.482 & $2.156^{* * *}(0.339)$ & 8.637 & $2.357^{* * *}(0.341)$ & 10.559 & $3.965 * * *(0.550)$ & 52.720 \\
\hline & \multicolumn{2}{|c|}{$43.270^{* * *}$} & \multicolumn{2}{|c|}{$64.194 * * *$} & \multicolumn{2}{|c|}{$73.830 * * *$} & \multicolumn{2}{|c|}{$116.703^{* * *}$} \\
\hline Pseudo $R^{2}$ & \multirow{2}{*}{\multicolumn{2}{|c|}{$\begin{array}{c}x^{2}=56.25(p=0.121) \\
1058.018(p=1.00)\end{array}$}} & & & & & 0.2 & \\
\hline $\begin{array}{l}\text { Test of parallel lines } \\
\text { Pearson chi-square }\end{array}$ & & & \multicolumn{2}{|c|}{$\begin{array}{c}x^{2}=49.078(p=0.072) \\
1471755(p=1.00)\end{array}$} & \multicolumn{2}{|c|}{$\begin{array}{l}x^{2}=50.847(p=0.097) \\
1723.709(p=0.997)\end{array}$} & \multicolumn{2}{|c|}{$\begin{array}{c}x^{2}=74.683(p=0.391) \\
1843.82(p=0.924)\end{array}$} \\
\hline
\end{tabular}

Note: Standard errors are in parentheses. ${ }^{* * *}, * *$, and ${ }^{*}$ indicate significance at the level of $0.01,0.05$ and 0.1 , respectively. OR $=$ odds ratio. JC $=$ junior college and above; PS $=$ primary school and below; JHS = junior high school; RSHS = regular senior high school; PHS = professional high school or technical secondary school. 
All six of the variables concerning the factor "firm attributes and skill preference" are involved in Model I. The overall fitting degree is good $\left(\chi^{2}=43.279, p<0.01\right)$, which shows that this factor has a significant effect on RUMWs' skill accumulation. Specifically, INFC4 and INFC5 have significant positive correlation under the levels of 0.1 and 0.01 . They represent "on-the-job training inside the firm" and "encouragement of learning by doing", respectively, and are the incentives for firms to promote RUMWs' skill accumulation. It also proves that $\mathrm{H} 1$ is tenable, namely, that the skill-oriented preference of a firm is positively correlated with RUMWs' skill accumulation. However, INFC1, INFC2, INFC3 and INFC6 do not show significant correlation with the dependent variable. INFC1, INFC2 and INFC3 represent the size, the ownership and the trade of firms respectively, indicating that these characteristics of firms do not have a significant impact on RUMWs' skill accumulation.

All four variables concerning the factor "collective efficiency" are involved in Model II. The chi-square value is 64.194 under the level of 0.01 of the ordered logistic regression equation, which means that the whole equation is significant. The four variables present significant positive correlation with RUMWs' skill accumulation. ITFC1 and ITFC2 present significant positive correlation under the levels of 0.05 and 0.01 , and they represent "inter-firm cooperation" and "inter-firm competition", respectively, indicating the inter-firm relationship significantly promotes RUMWs' skill accumulation. When firms compete for technical workers, RUMWs will have more motives to enhance their vocational skills; moreover, abundant firms in the same sector can conduct economic and technical cooperation to benefit the flow of different kinds of knowledge and skills among firms and to further increase the opportunities of RUMWs to learn skills. It proves that $\mathrm{H} 2$ is tenable, that the collective efficiency among local firms is positively correlated with the skill accumulation of RUMWs. ITFC3 and ITFC4 also present significant correlation under the level of 0.05 , which means that more job opportunities and the higher local skill demand as a result of geographical agglomeration of firms in the related sectors contribute to RUMWs' skill accumulation; in other words, external economies and consistency in demand for higher-skilled labor in the local labor market promote RUMWs' skill accumulation.

All five of the variables concerning "accessibility non-firm institutions" are involved in Model III, and the ordered logistic equation is significant as the chi-square value is 73.830 under the level of 0.01 . NFR1, NFR4 and NFR5 present significant positive correlation under the level of $0.05,0.1$ and 0.01 , respectively, indicating that the non-firm institutions including the public cultural facilities, VTOs and fellow townsman communities, help RUMWs accumulate vocational skills. However, NFR2 and NFR3 fail to pass significance testing. Local governments are very concerned with the employment and skill accumulation of local residents, while paying little attention to RUMWs, so the skill accumulation of RUMWs does not actually benefit much from local incentive policies. As NGOs are still in development in the two research areas, few RUMWs could benefit from such organizations. In general, Model III proves $\mathrm{H} 3$ is tenable, namely, the accessibility of local non-firm institutions is positively correlated with RUMWs' skill accumulation.

The control variable "regional factor" is significant under the level of 0.05 in Model I, II, III, and its regression coefficients are positive in each model. Since the measurement of this index takes Suzhou as a benchmark, it means regional difference is significant and RUMWs' skill accumulation in Yuhuan is higher than that in Suzhou. The results of the questionnaire survey also prove this point: 261 respondents consider that their skills are significantly improved (the average assignment of skill improvement is $\geq 4$ ), making up $53.2 \%$ of the total respondents. This ratio in Yuhuan is $62.1 \%$, much higher than that in Suzhou (only 43.4\%). Conversely, 114 respondents believe that their skills are not significantly improved (the assignment of skill improvement is $\leq 2$ ), making up $23.2 \%$ of the total respondents. This ratio in Yuhuan is $17.9 \%$, significantly lower than that in Suzhou (28.9\%).

ID1, a control factor related to "individual factors", has no significant effect in Model I, II and III, indicating that gender has no significant effect on RUMWs' skill accumulation. In addition, the ID3 is only significant at the level of 0.1 in Model I, and has no significant effect in Model II and III, meaning that the length of service is not an important factor affecting RUMWs' skill accumulation. The variable 
"professional high school or technical secondary school" of ID2 are significant at the level of 0.05, and its regression coefficients are negative, as the variable "junior college and above" is a reference. This result indicates that the RUMWs whose education level is junior college or above would have more improvement on vocational skills than those whose education level is professional high school or technical secondary school. Although other education levels do not show significant correlation, the significant effect of "professional high school or technical secondary school" indicates that the education level before migrant work of RUMWs actually influences their skill accumulation during their migrant work. The ID4 is significant at the level of 0.05 in the three models, and its regression coefficients are positive. Since the measurement of this index takes "choosing the firm you work in for other reasons" as a benchmark, this result indicates that improving skills as the main reason for RUMWs' job hunting significantly facilitates their skill accumulation in the firm they worked in. In other words, RUMWs' self-selection has a significantly positive effect on their skill accumulation. However, only about $30 \%$ of the total respondents viewed skill accumulation as the most important reason to accept the current job opportunity in the questionnaire, $14 \%$ lower than the top reason, "for more income".

In Model IV, all variables are involved in the regression model, and the whole equation is significant as the chi-square value is 116.703 under the level of 0.01 . Eight of 20 variables, RG, ID2, ID4, INFC4, INFC5, ITFC2, NFR4, and NFR5, show significant correlation with RUMWs' skill accumulation. These eight significant variables are also significant in Model I, II, and III, whereas the other five variables, ID3, ITFC1, ITFC3, ITFC4 and NFR1, which present significant correlation in Models I, II, and III, fail to pass significance testing in Model IV. Among these seven significant variables, RG, NFR5, ID4, ITFC2, and INFC5, belonging to regional factor, accessibility of non-firm institutions, individual factors, collective efficiency, and firm attributes and skill preference, respectively, are the top five factors influencing RUMWs' skill accumulation, and their odds ratios are 1.433, 1.239, 1.266, 1.186, and 1.169 respectively. Compared with intra-firm factors, local non-firm institutions (especially local fellow townsman communities) and inter-firm co-competitive relationship contribute more to the RUMWs' skill accumulation. It implies that the "place" as a space of various kinds of relationships has an important role in the RUMWs' skill accumulation besides the economic entities themselves.

\section{Conclusions and Discussion}

International economics literature is very concerned with the relationships between international activities, innovation, and labor's skill upgrading in LDCs. However, individual workers' skill accumulation/upgrading is rarely considered and the discussion of unorganized labor, especially migrant workers outside the mainstream labor market is still insufficient. Focusing on RUMWs, unorganized laborers, this paper takes China, a developing country undergoing economic transition from "Made in China" to "Create in China", as an example to explore the factors influencing their skill accumulation. Unlike the extant literature on skill upgrading, which generally focuses on the effects of global activities, this paper concerns itself with the effects of localization on laborers' skill accumulation in the context of globalization by using an analytical framework based on international economics literature and industrial clusters research, and goes beyond the view of national institutional barriers concerning household registration in China. It explores different regions inside a country instead of looking at that country as a whole, and rather than standing on the demand side, takes the perspective of individual laborers. It adopts a broad viewpoint containing intra-firm skill-biased strategy (as a response to intense competition), inter-firm relationships, and accessibility of local non-firm organizations. In particular, it finds that inter-firm relationships, representing collective efficiency of local value chains, are beneficial in promoting RUMWs' skill accumulation and in maintaining the sustainability of local development, which is seldom mentioned in the extant literature. Additionally, the place itself, as a synthesized space of labor-management relations inside a firm and inter-organization relations, exerts an influence on and causes regional differences in RUMWs' skill accumulation. These findings contribute to a deeper understanding of how to sustain or reshape 
competitive advantage through the improvement of workers' skill accumulation, and suggest that collective coordination and efficiency of local production systems (rather than that of the local value chain mentioned above) should be taken into account for designing and implementing regional skill-upgrading-related policy.

This research also draws some conclusions. Firstly, firms' skill-oriented preferences, which are concerned with employees' skills and innovation ability and stimulate them to learn with initiative, have a significant influence on RUMWs' skill accumulation. Secondly, collective efficiency, based on the co-competitive relationship between local firms, has a significant influence on RUMS' skill accumulation. That is to say, the more intensive interactions between local firms are, the more learning opportunities and knowledge spillovers occur to promote skill accumulation for RUMWs. Thirdly, the accessibility of local institutions and favorable policies is beneficial for RUMWs to improve skill accumulation. In particular, training programs from local VTOs and mutual learning inside the local communities of RUMWs are two important channels of skill accumulation. Furthermore, RUMWs' skill accumulation of labor in Yuhuan is higher than that in SIP, which demonstrates the importance of place as a synthesized space of multiple factors. In addition, although local firms in the two areas have directly or indirectly engaged in international trade, it does not show the significant effects of globalization on RUMWs' skill accumulation mentioned in the extant literature, and also shows no significant difference in skill accumulation between foreign and private firms.

However, this paper suffers from the following defects. Firstly, variable selection and connotation definition in the questionnaire should be further improved. For example, standards in the three aspects are set up in the paper to assist the respondents in measuring "skill improvement" in a quantified way. However, there exists a certain degree of subjectivity. Some variable's measurements, especially those concerning firms' international activities or global relationships, are quite rough, and do not consider some important aspects, such as imported advanced machinery, and the amount of imports and exports. The two relevant independent variables (firm ownership and international trade) not showing significance to skill accumulation could be caused by this. The depiction of inter-firm relationships fails to subdivide into relations with the upper and lower streams of the value chain and peer firms, respectively. Secondly, the research focuses on RUMWs in the manufacturing industry and the findings should be further tested in other sectors. For example, the positive influence of the "regional factor" in Suzhou is less than that in Yuhuan, which is confirmed in the latest communication with local experts in Suzhou. However, it has also been learned that the service quality and personnel quality of tertiary industries in Suzhou have been quickly improving due to the influx of abundant foreign investments and the effect goes far beyond the manufacturing industry. In addition, the questionnaires were issued in two areas, and the number of large firms involved in effective questionnaires is still few. The research findings should be verified in other regions and through an increase in sample coverage.

Acknowledgments: This research is supported by the National Natural Science Foundation of China (project code: 41171098, 41471121). The authors would also wish to extend their thanks to three anonymous reviewers for their valuable comments, and to Guiqin Qian, Yubing Zhang, and Weiqin Wang for their help during the questionnaire survey.

Author Contributions: Huasheng Zhu contributed to the analytical framework and the methodology design and wrote the article. Junwei Feng and Maojun Wang contributed to the data analysis. Fan Xu sent out questionnaires and collected data.

Conflicts of Interest: The authors declare no conflict of interest.

\section{References}

1. Ogunade, A.O. Human Capital Investment in the Developing World: An Analysis of Praxis; Seminar Research Paper; University of Rhode Island: Kingston, NY, USA, 2011.

2. Lall, S. Competing with Labor: Skills and Competitiveness in Developing Countries; Issues in Development Discussion Paper 31; ILO: Geneva, Switzerland, 1999. 
3. Lee, E.; Vivarelli, M. The social impact of globalization in the developing countries. Int. Labour Rev. 2006, 145, 167-184. [CrossRef]

4. Fanjnzylber, P.; Fernandes, A. International economic activities and skilled labour demand: Evidence from Brazil and China. Appl. Econ. 2009, 41, 563-577. [CrossRef]

5. Accetturo, A.; Bugamelli, M.; Lamorgese, A.R. Skill upgrading and exports. Econ. Lett. 2013, 121, 417-420. [CrossRef]

6. Mayer, J. Globalization, Technology Transfer and Skill Accumulation in Low-Income Countries; UNCTAD Discuss Paper 150; UNCTAD: Geneva, Switzerland, 2000.

7. Verhoogen, E.A. Trade, quality upgrading, and wage inequality in the Mexican manufacturing sector. Q. J. Econ. 2008, 123, 489-530. [CrossRef]

8. Bustos, P. The Impact of Trade Liberalization on Skill Upgrading. Evidence from Argentina; Barcelona Graduate School of Economics Working Paper 559; UPF: Barcelona, Spain, 2011.

9. Haile, G.; Srour, I.; Vivarelli, M. Imported technology and manufacturing employment in Ethiopia. Eurasian Bus. Rev. 2016. [CrossRef]

10. Hornery, R. Strategic decoupling, recoupling and global production networks: India's pharmaceutical industry. J. Econ. Geogr. 2014, 14, 1117-1140. [CrossRef]

11. Hahn, C.H.; Park, C.G. Exporting, Employment, and Skill Upgrading: Evidence from Plant Level Data in the Korean Manufacturing Sector; OECD Publishing: Paris, France, 2011.

12. Cai, Y.H. Migrant Workers: The Motivity of Urbanization in China. Available online: http://www.chinacity. org.cn/cstj/csh/54336.html (accessed on 7 April 2010).

13. National Bureau of Statistics of China. Monitoring Report of Peasant Workers in 2013. Available online: http:/ /www.stats.gov.cn/tjsj/zxfb/201405/t20140512_551585.html (accessed on 12 May 2014).

14. Chan, K.W. The household registration system and migrant labor in China: Notes on a debate. Popul. Dev. Rev. 2010, 36, 357-364. [CrossRef] [PubMed]

15. Wong, K.; Fu, D.; Li, C.Y.; Song, H.X. Rural migrant workers in urban China: Living a marginalised life. Int. J. Soc. Welf. 2007, 16, 32-40. [CrossRef]

16. Chen, G.; Hamori, S. Solution to the dilemma of the migrant labor shortage and the rural labor surplus in China. China World Econ. 2009, 17, 53-71. [CrossRef]

17. ChinaIRN.com. Start to Implement the Upgrading Peasants' Skills Plan This Year in China. Available online: http:/ / www.chinairn.com/news/20140731/092232365.shtml (accessed on 31 July 2014).

18. Chan, K.W. The global financial crisis and migrant workers in China: There is no future as a labourer; returning to the village has no meaning. Int. J. Urban Reg. Res. 2010, 34, 659-677. [CrossRef]

19. Taylor, J.E.; Yunez-Naude, A. The returns from schooling in a diversified rural economy. Am. J. Agric. Econ. 2000, 82, 287-297. [CrossRef]

20. Maazouz, M. Return to investment in human capital and policy of labour market: Empirical analysis of developing countries. Procedia Econ. Financ. 2013, 5, 524-531. [CrossRef]

21. Heckman, J.J. China's Investment in Human. Cap. Econ. Dev. Cult. Chang. 2003, 51, 795-804. [CrossRef]

22. Heckman, J.J. China's human capital investment. China Econ. Rev. 2005, 16, 50-70. [CrossRef]

23. Bassanini, A. Training, wages and employment security: An empirical analysis on European data. Appl. Econ. Lett. 2006, 13, 523-527. [CrossRef]

24. Budría, S.; Pereira, P.T. The wage effects of training in Portugal: Differences across skill groups, genders, sectors and training types. Appl. Econ. 2007, 39, 787-807. [CrossRef]

25. Becker, G.S. Investment in human capital: A theoretical analysis. J. Political Econ. 1962, 70, 9-49. [CrossRef]

26. Stark, O.; Helmenstein, C.; Prskawetz, A. Human capital depletion, human capital formation, and migration: A blessing or a "curse"? Econ. Lett. 1998, 60, 363-367. [CrossRef]

27. Wang, M.Y.; Wu, J. Migrant workers in the urban labour market of Shenzhen, China. Environ. Plan. A 2010, 42, 1457-1475. [CrossRef]

28. Ngok, K. Serving migrant workers: A challenging public service issue in China. Aust. J. Public Adm. 2012, 71, 178-190. [CrossRef]

29. Chan, C.K.C. Community-based organizations for migrant workers' rights: The emergence of labour NGOs in China. Community Dev. J. 2012. [CrossRef]

30. Seeborg, M.C.; Jin, Z.; Zhu, Y. The new rural-urban labor mobility in China: Causes and implications. J. Soc. Econ. 2000, 29, 39-56. [CrossRef] 
31. Zhao, Y. Causes and consequences of return migration: Recent evidence from China. J. Comp. Econ. 2002, 30, 376-394. [CrossRef]

32. Cheng, Z.; Wang, H.; Smyth, R. Happiness and job satisfaction in urban China: A comparative study of two generations of migrants and urban locals. Urban Stud. 2014, 51, 2160-2184. [CrossRef]

33. Ma, Y.R.; Huang, K.S. The Mechanism of Urbanization influence the Human Capital Investment and Accumulation of New Generation of Migrant Workers. Acad. Forum 2014, 7, 124-128. (In Chinese)

34. Zuo, W.; Wang, Q.; Yang, P. Research on the current situation of peasant-workers in construction industry based on AHP. Syst. Eng. Procedia 2012, 5, 405-411. [CrossRef]

35. Hanson, G.; Harrison, A. Trade and wage inequality in Mexico. Ind. Labor Relat. Rev. 1999, 52, $271-288$. [CrossRef]

36. Meschi, E.; Taymaz, E.; Vivarelli, M. Trade, technology and skills: Evidence from Turkish microdata. Labour Econ. 2011, 18, 60-70. [CrossRef]

37. Almeida, R. Openness and Technological Innovation in East Asia: Have They Increased the Demand for Skills? IZA Discussion Papers 4474; IZA: Bonn, Germany, 2009.

38. Lall, S. The Employment Impact of Globalization in Developing Countries; QEH Working Paper 93; Palgrave Macmillan: New York, NY, USA, 2004.

39. Robbins, D.J. Evidence on Trade and Wages in the Developing World. Available online: https://ideas.repec. org/p/oec/devaaa/119-en.html (assessed on 13 December 2016).

40. Vivarelli, M. Globalization, skills and within-country income inequality in developing countries. In Understanding Globalization, Employment and Poverty Reduction; Lee, E., Vivarelli, M., Eds.; Palgrave Macmillan: New York, NY, USA, 2004; pp. 211-243.

41. Ngai, P.; Chan, J. Global capital, the state, and Chinese workers the Foxconn experience. Mod. China 2012, 38, 383-410. [CrossRef]

42. Vivarelli, M. Innovation, employment and skills in advanced and developing countries: A survey of economic literature. J. Econ. Issues 2014, 48, 123-154. [CrossRef]

43. Salomon, R.M.; Shaver, J.M. Learning by exporting: New insights from examining firm innovation. J. Econ. Manag. Strategy 2005, 14, 431-460. [CrossRef]

44. Wagner, J. Exports and productivity: A survey of the evidence from firm-level data. World Econ. 2007, 30, 60-82. [CrossRef]

45. Gkypali, A.; Rafailidis, A.; Tsekouras, K. Innovation and export performance: Do young and mature innovative firms differ? Eurasian Bus. Rev. 2015, 5, 397-415. [CrossRef]

46. Mitra, A.; Jha, A.K. Innovation and employment: A firm level study of Indian industries. Eurasian Bus. Rev. 2015, 5, 45-71. [CrossRef]

47. Pavcnik, N. What explains skill upgrading in less developed countries? J. Dev. Econ. 2003, 71, 311-328. [CrossRef]

48. Antonelli, G.; Antonietti, R.; Guidetti, G. Organizational change, skill formation, human capital measurement: Evidence from Italian manufacturing firms. J. Econ. Surv. 2010, 24, 206-247. [CrossRef]

49. Taj, S.; Morosan, C. The impact of lean operations on the Chinese manufacturing performance. J. Manuf. Technol. Manag. 2011, 22, 223-240. [CrossRef]

50. Pine, B.J. Mass Customization: The New Frontier in Business Competition; Harvard Business School Press: Boston, MA, USA, 1993.

51. Destré, G.; Lévy-Garboua, L.; Sollogoub, M. Learning from experience or learning from others? Inferring informal training from a human capital earnings function with matched employer-employee data. J. Soc. Econ. 2008, 37, 919-938. [CrossRef]

52. Mathews, J.A.; Cho, D.S. Tiger Technology: The Creation of a Semiconductor Industry in East Asia; Cambridge University Press: Cambridge, UK, 2007.

53. Keeble, D.; Lawson, C.; Moore, B.; Wilkinson, F. Collective learning processes, networking and 'institutional thickness' in the Cambridge region. Reg. Stud. 1999, 33, 319-332. [CrossRef]

54. Bathelt, H.; Malmberg, A.; Maskell, P. Clusters and knowledge: Local buzz, global pipelines and the process of knowledge creation. Prog. Hum. Geog. 2004, 28, 31-56. [CrossRef]

55. Vona, F.; Consoli, D. Innovation and skill dynamics: A life-cycle approach. Ind. Corp. Chang. 2015, 24, 1393-1415. [CrossRef]

56. Propris, L.D. Types of innovation and inter-firm co-operation. Entrep. Reg. Dev. 2002, 14, 337-353. [CrossRef] 
57. Zeng, S.X.; Xie, X.M.; Tam, C.M. Relationship between cooperation networks and innovation performance of SMEs. Technovation 2010, 30, 181-194. [CrossRef]

58. Landry, R.; Amara, N.; Lamari, M. Does social capital determine innovation? To what extent? Technol. Forecast. Soc. Chang. 2002, 69, 681-701. [CrossRef]

59. Ceci, F.; Iubatti, D. Personal relationships and innovation diffusion in SME networks: A content analysis approach. Res. Policy 2012, 41, 565-579. [CrossRef]

60. Schmitz, H. Collective efficiency: Growth path for small-scale industry. J. Dev. Stud. 1995, 31, 529-566. [CrossRef]

61. Peng, T.J.A. Resource fit in inter-firm partnership: Intellectual capital perspective. J. Intell. Cap. 2011, 12, 20-42. [CrossRef]

62. Maliranta, M.; Mohnen, P.; Rouvinen, P. Is inter-firm labor mobility a channel of knowledge spillovers? Evidence from a linked employer-employee panel. Ind. Corp. Chang. 2009, 18, 1161-1191. [CrossRef]

63. Albino, V.; Garavelli, A.C.; Schiuma, G. Knowledge transfer and inter-firm relationships in industrial districts: The role of the leader firm. Technovation 1998, 19, 53-63. [CrossRef]

64. Henry, N.; Pinch, S. Neo-Marshallian nodes, institutional thickness, and Britain's 'motor sport valley': Thick or thin? Environ. Plan. A 2001, 33, 1169-1183. [CrossRef]

65. Parrilli, M.D.; Aranguren, M.J.; Larrea, M. The role of interactive learning to close the "Innovation Gap" in SME-Based Local Economies: A furniture cluster in the Basque Country and its key policy implications. Eur. Plan. Stud. 2010, 18, 351-370. [CrossRef]

66. Amin, A.; Thrift, N. Globalization, Institutions, and Regional Development in Europe; Oxford University Press: Oxford, UK, 1995.

67. Cooke, F. Vocational and enterprise training in China: Policy, practice and prospect. J. Asia Pac. Econ. 2005, 10, 26-55. [CrossRef]

68. Yao, Y.; Zhong, N. Unions and workers' welfare in Chinese firms. J. Labor Econ. 2013, 31, 633-667. [CrossRef]

69. Liu, Y.; Li, Z.G.; Breitung, W. The social networks of new-generation migrants in China's urbanized villages: A case study of Guangzhou. Habitat Int. 2012, 36, 192-200. [CrossRef]

70. Liu, Y.L. Reform from below: The private economy and local politics in the rural industrialization of Wenzhou. China Q. 1992, 130, 293-316. [CrossRef]

71. Wei, Y.D.; Li, W.; Wang, C. Restructuring industrial districts, scaling up regional development: A study of the Wenzhou model, China. Econ. Geogr. 2007, 83, 421-444. [CrossRef]

72. International Labor Office. Skills Development through Community Based Rehabilitation: A Good Practice Guide; ILO Press: Geneva, Switzerland, 2008.

73. De Kok, J. The impact of firm-provided training on production testing for firm-size effects. Int. Small Bus. J. 2002, 20, 271-295. [CrossRef]

74. Ng, Y.C.; Siu, N.Y. Training and enterprise performance in transition: Evidence from China. Int. J. Hum. Resour. Manag. 2004, 15, 878-894. [CrossRef]

75. Vendryes, T. Migration constraints and development: Hukou and capital accumulation in China. China Econ. Rev. 2011, 22, 669-692. [CrossRef]

(C) 2017 by the authors; licensee MDPI, Basel, Switzerland. This article is an open access article distributed under the terms and conditions of the Creative Commons Attribution (CC-BY) license (http://creativecommons.org/licenses/by/4.0/). 